\title{
“Mass Production” in the Mass Consumption Societies: The Case of Male Bodybuilding
}

\author{
Guillaume Vallet \\ University of Grenoble-Alpes, Grenoble, France; \\ University of Geneva, Geneva, Switzerland; \\ Ecole des Hautes Etudes en Sciences Sociales of Paris, Paris, France
}

\begin{abstract}
Nowadays, the body seems to be the perfect object of consumption. People use it to define themselves but also as a vehicle that can send signs to others in the hope that their body will be a factor of social integration and social recognition. Hence we can observe the development of practices of body transformations which go along with the philosophy of the society in which everything seems possible for everybody, with no limit whatsoever. Indeed, if you want your body to be seen, you have to "produce" it before. The practice of bodybuilding sustains efforts in that direction: historically born and developed along with the consumption society, it came to embody its values. The analysis is based on qualitative methodology that is observations in three bodybuilding Gyms and 30 interviews with bodybuilders in France. The results show that bodybuilding reflects the consumption society's norms, that is a practice in which the body is in tension between imitation and distinction, hence showing the will to be "like others but in better" thanks to the production of a nice and "massive" body. Such a dimension could sometimes be dialectical, when the body becomes a source of alienation.
\end{abstract}

Keywords: bodybuilding, capitalism, consumption societies

\section{Introduction}

During the 20th century, Western societies have turned from "production societies" to "consumption societies". From an economic perspective, as Rostow (1991) argues, the means that once the take-off process has been achieved, the economic system has to develop standardisation with the aim of producing for the whole population. This indicates that the main social challenges and conflicts are not only in the production area, but also and maybe more in the consumption area: The social recognition and the individual identity of a person are strongly linked to their ability to demonstrate something to the others by consuming. If such attitudes used to exist during other periods, as Tocqueville (2004) or Simmel (2011) highlighted for example, it seems that they have taken more importance during the past 50 years. The latter have been indeed marked by the questioning of ideologies (religious, political, ... ), the difficulties of the nation-state as a central institution, and the debates about the place of job in our societies. Those evolutions tend to accelerate the rise of individualization and even

Guillaume Vallet, Ph.D., associate professor, Department of Economics, University Grenoble-Alpes; Department of Sociology, University of Geneva; Department of Sociolgy, Ecole des Hautes Etudes en Sciences Sociales of Paris. 
individualism (Bauman, 2000), entailing that the most part of social life is oriented towards individual satisfaction provided that it is showed to others.

Hence, in such "consumption societies”, objects that one possesses are important to build a social status, to be positively labellized by others. In this context, the body appears to represent the perfect object of consumption (Baudrillard, 1998). People use it not only to define themselves but also as a vehicle that can send signs to others in the hope that their bodies will be a factor of social integration and social recognition. That would explain why people turn to their body, as a support of intimacy and differentiation. Hence we can observe the development of practices of body transformations which go along with the contemporary philosophy in which everything seems possible for everybody, with no limit whatsoever (Blake, 1996). The practice of bodybuilding sustains efforts in that direction: historically born and developed along with the consumption society, it came to embody its values. Particularly, a muscular body symbolizes for the persons who practice this sport a high-performance body that is highly valued. And as they think this body is nicer and stronger than the others, they can exhibit it to attract people's glance (Vallet, 2013).

But such a body which is used in this market of signs has to be produced first: the signs circulation process depends on the production one. In others words, in order to comprehend to what extent the body can here play a central role in our "consumption societies", it is necessary to investigate the way a person transforms it from a resource to a capital too. Once again, bodybuilding seems to be very relevant in this case because it is based on a "Mass Production” implying hard work, pain, and asceticism (Monaghan, 2001; Vallet, 2013). Knowing that such a personal project is about gender (Klein, 1993; Berry, 2010; Denham, 2010), we make the choice to focus on another often forgotten but relevant aspect of this sport. So we shall tackle the following issue: to what extent is bodybuilding both the reflection and the vector of the main principles of our contemporary consumption societies?

The first part emphasizes on the particularities of such societies as well as the status and the place of the body in them. The second focuses on the appeal of bodybuilding for some people in such a context: as this sport presents itself as the best way to transform the human body thanks to individual efforts, it could be very attractive. The third deals with the ambivalent aspects of such a body mass production: based on observations in three Gyms and 30 interviews with bodybuilders conducted in France, we will explain why the body is in tension between imitation and distinction, implying both a liberation and an alienation process.

\section{The Weight of the Body Today}

The social conception of the body is very different according to the societies and the historical periods. In western societies, if the body used to have a low value with Platon (the 4th and 5th centuries before J.C.) and with the dominance of Catholicism, it has gained value with the modern conception that has appeared since the 18th century. First, as Weber (2012) highlighted, the development of the Protestant ethic induced that the body was considered as a major tool to create wealth in the hope of attracting God's glance and evacuating the anxiety to be damned. But the body became a new field of investment in the current life here below: It could and had to be rationalized too. So such an evolution created a more attractive status for the body (Taranto, 2008).

But more generally, this period is convenient in major philosophical, technical, and medical progresses which have participated in creating a new imaginary towards the body: the latter is a convertible object, located 
in a perpetual "no limit path". This explains why during the two following centuries such a vision has influenced another conception that is the possibility of a "subject body": through its care, a person could really reach wisdom, happiness, self-knowledge, in a process where body and soul merge (Maisonneuve, 1976; Shilling, 2012).

Nowadays, we would be in the "second modernity” of the body (Bonetti, De Gaulejac, Descendre, \& Pagès, 1998). In such an era, the individual centration on the body is accentuated, because a person looks for excess, overtaking and maximum risks (Baudry, 1991; Beck, 1992). In this way, the body is the perfect resource that everybody possesses and could use to give sense to life (Turner, 2008), or even become a safety anchor (Moore, 1996). Thus the body has an important status for an individual: thanks to it, he could transform himself by transforming it, allowing him to be more narcissistic (Lasch, 1991) as well as becoming more attractive in the interactions. In such a social context where a person is the core of the system, reflexivity behaviors rise (Giddens, 1991).

Indeed, bodily display seems to have taken a growing importance in the interactions, implying that one can be labellized as normal or deviant (Becker, 1963; Goffman, 1963) regarding to the characteristics of their bodies (Amadieu, 2005). The normal body gives access to positive recognition and thus is able to attract someone's glance. That is what we call the "gravitational body". Conversely, the deviant body is perceived as a stigma that someone wants to hide, because it has a reduced or no value in our societies (Queval, 2008). At the opposite, the example of obesity perfectly indicates to what extent such a fat body embodies an individual laisser aller and then a person who does not have the sense of responsibility. These two behaviors are badly judged (Queval, 2008). The growing medicalization of life sustains efforts in that direction too. The reference to health has become a norm and even a virtue in a world which would have lost its marks. Health would be both a right and a duty, and the body would be the reflection of it. The condition of it, is to register the body in a continual improvement path, that means a "better, faster, stronger" and rationalized process. The previous developments indicate that if the whole body is involved in this process, not all the bodies are welcome: only the successful ones are valued, that is the muscled, lean and low fat bodies. Fat is perceived as a useless burden a person has to eliminate.

Bodybuilding perfectly fits such a requirement: This sport is based on the body's muscular development but with minimal fat levels.

\section{Bodybuilding as a Consumerist Socioeconomic System}

In our consumption societies, bodybuilding has benefited from the context emphasizing on the fact that to show off one's body is visible health (Klein, 1993). But if we want the body to be seen, we have first to pay attention to it, following the principle of free entrepreneurship. In the practice of bodybuilding, this goes along with a hard and organized work aiming at the production of the required mass. Our observations, which have been done in three French gyms from August 2009 to May 2010 (120 observations exactly), show how the work out goes on: Most of the bodybuilders follow a very strict routine, with precise and defined exercises, series and repetitions. Furthermore, some of them use chronometers to be regular in the performance. Time is clearly gain. And you can evaluate your own performance in real time thanks to mirror as well as mirrors on the wall that will boost you. For example, it is written in big letters on a poster: "maximum results, minimum time”. 
Hence the body is both the tool and the result of such a work. Twenty-seven out of the 30 bodybuilders interviewed even directly use the word "work" during the interview. While still a beginner, Vincent (18 years old, who has been doing bodybuilding for four years), gives priority to work over leisure and discussions during training: "Of course, I will never send somebody off when I'm training, it's a question of savoir-vivre, nevertheless...” (personal communication, January 20, 2010). It is also crucial to rationalize all the aspects of your life if you want to succeed and reach your goals: you have to pay attention to your nutrition, several products that you consume as well as the people you see (Monaghan, 2001). As Darmon (2008) highlights with anorexia, which relies on the same principles of work than bodybuilding according to us, such a work of and on the body always implies a work "for" and a work "against”. For instance, Claude (28 years old, bodybuilder for 10 years) often finds strategies to manage to apply this logic and logistic even if it implies sacrifices:

The worst thing for me is the family Sunday lunch ... you see what I mean, when people don't want to adapt to you, then you have to adapt to them. So, you know what I do on Sundays, I just grub a little before going to lunch, and once there, I grub a few mouthfuls, just to show that I'm eating something, and I even say to them: “I went out last night, I'm not very hungry”. (personal communication, May 15, 2010)

Nevertheless, such a hard work is temporary by nature: the bodybuilder has to always think about the way to push away the borders of his body, as Claude cited just above underlines during the interview, when we talk about limits: "I have no limits whatsoever. If I can be the world champion, then I just do it" (personal communication, May 15, 2010).

Such a sport shares then with other social activities the main principle of our consumption societies: it relies on the perpetual creation of new needs, necessitating transforming resources into accumulated capital. This implies for the bodybuilder a permanent frustration which he has to deal with. This also induces for him the fact that he wants to improve his body to reach the ideal body of the sport: maximum muscle mass, minimal fat and water levels, and symmetry and equilibrium of the different muscles (Perine, 2010). This process is hence based on strong ties between production and consumption eras: the "mass" production depends on performance during training as well as in the whole life, in particular through nutrition (Luciano, 2001). A bodybuilder has to eat a lot of proteins and calories to build muscles, showing that he is entirely a member of the consumer societies due to his growing needs. But it is important to notice that gains value only through a social validation that is through competitions and more often interactions. Conversely, the latter give a price to the body, which is an invitation to go further into the involvement.

That is why we consider why such a body is the "nicest consumption society's object" (Baudrillard, 1970). Indeed, even if bodybuilding took some of its roots in some activities and aesthetical demonstration of the naked body during the Antiquity (Prost, 2006; Young, 1984), it is above all strongly linked to the industrial era that really took place in western societies at the end of the 19th century. At this time, bodybuilding borrowed some of its principles of weight lifting to ancient traditional popular games that used to produce "big bodies" as well as enhance and control the body as the German gymnastic did. The goal was to do the best to improve the human body (Chartier \& Vigarello, 1982; Defrance, 2003).

During this period, athletes like Eugen Sandow or Charles Atlas after him used to lift heavy weight, mainly to show off their body and in demonstrations, slowly launching the idea that body appearance could be a strong and unique criterion to evaluate such athletes (Schwarzenegger, 1998). So from the 1950s till today, competitions 
have been set up where only hypermuscular, low-fat and symmetrical bodies have a chance to win. That is the case for the main competitions as Mr. Olympia, the most famous competition of bodybuilding in the world, anchored to the powerful International Federation of Bodybuilding. The latter, created by Joe and Ben Weider during the 1940s, relies on consumption societies' principles too. Firstly, it works thanks to the logic of spectacular bodies that represent the way to follow for the bodybuilders: "In this way, when I see one of them, I say to myself 'this one looks quite good, I'd like to be like him'” (Mohamed, 34 years old, who has been doing bodybuilding for 14 years) (personal communication, March 4, 2010).

This reinforces the principle of self-help and meritocracy, which can give access to money. The case of Schwarzenegger is strongly relevant here: what has attracted Fabrice (28 years old, the 11th in bodybuilding) is to "See Arnold on television ... (laughters). When I was a child, he was my model, he was, ... and there was also Stallone and a few others, but I wanted to be like Arnold when I grew up” (personal communication, March 13, 2010). And that is the reason why he is constantly looking for:

Massive bulk today... yes, massive bulk. For me, what matters is massive bulk indeed (laughters). Now, I'd like to have a nicer bodily line, but I must admit that what I'm striving at is massive bulk... the bigger I get, the happier I am. When I see on the scales that I have put on weight (1kg), I’m overjoyed!. (personal communication, March 13, 2010)

Secondly, such physicals are shown through competitions, and overall specific media, that influences the aesthetical body norms whose bodybuilders refer to. To relate this, we have analyzed 30 numbers specialized reviews. It seems that two main functions emerge out of them: to sell numbers, and to spread the imaginary showing to bodybuilders that if they want to transform their body, they can, and that such a body will give them several benefits (Klein, 1993; Duret, Griffet, \& Roussel, 2003). This norm works easily because it seems to have been chosen by bodybuilders themselves.

And the previous element goes along with all the advertising for different products that create a whole system of mass consumption: in the Flex magazines, almost half of the pages of the review contains advertising. Industrial companies put into light products that will help the bodybuilder to reach his goals, but with the caution of science and the support of a champion.

Antoine (29 years old, has been practicing for 12 years) argues:

You know, you'll always have those kinds of magazines coming from the U.S. - what I call the 'veterinary mags or ox mags' because every two pages is dedicated to speak in praise of the qualities of such or such product, they display guys the same size as us but weighing $140 \mathrm{kgs}$, and all of them are lean ... We can easily guess that they don't take just a little dose of amino-acid, you'll agree with me. Well, it's not just the fact that it makes you dream of it, but you say to yourself 'okay, they're big, they're strong' ... then of course, you'll end by buying some. (personal communication, May 2, 2010)

To sum up, bodybuilding nowadays partakes in tackling the double issue: "Which body by which society and which body for which society?” (Berthelot, 1983). A bodybuilder has to invest his body and always go beyond. The body is a private resource which symbolizes freedom to invest, entrepreneurship, free work and profit (economically or symbolically), that is "no pain, no gain":

Let's say that bodybuilding is one of those sports in which you can actually see the results with your own eyes, so that's what makes it interesting, you see. It's true that you still have the artistic side of it, but above all, it's a question of results and performances, the fact that you can see that you're making progress (Alex, 37 years old, the 7th in bodybuilding). (personal communication, March 25, 2010) 
The apparent single project of a bodybuilder producing his body during work out and life to be able to consume it in the interactions has actually to be linked to a whole socioeconomic system that is a framework and a pillar of our current consumption societies.

That is why bodybuilding is in fact similar to other characteristics of our consumption societies, and their ambivalences in particular. Indeed, consumption of the body could both give sense to a person, giving her freedom, as well as being destroying if the whole life depends on such consumption. We develop this in the first part.

\section{The "Schizophrenic Body” of Bodybuilding: Freed or Burden Mass?}

The body of bodybuilding embodies two other features of our contemporary societies, namely hedonism and eudemonism. The first is about pleasure and leisure, and the second one deals with welfare. In other words, the transformation of the body means a transformation of the self. This could be relevant for people who feel bad with themselves, knowing that bodybuilding is a sport strongly attractive for those who feel weak or lack something (Klein, 1993). It is at the core of the dialectic interiority-exteriority (Vallet, 2008): An internal weakness would be compensated by a strong appearance. We have to notice that such a sport as a whole has grown up on this basis. Atlas cited above used to underline in its comics in the 1930s that a muscular body prevents the owner from being laughed at by other men and is very useful to attract women's glance:

I advise you to order my coursebook, then nobody will never ever dare to throw sand on your face. In record time, you'll become an exceptional man and you'll display your body on Venice beach, and be successful with girls. (Schwarzenegger, 2013, p. 140)

Moreover, Joe Weider, the former historic president of the IFBB (International Federation of Bodybuilding) (recently dead in 2013), and who, since the 1950's, has built a strong industry in medias, material and products dedicated to bodybuilding, used to explain on its personal website or in books to what extent bodybuilding represents the best way in life to be your best. To build a body gives access to self secure feelings and to a positive self-image that is very helpful in interactions (Reynolds \& Weider, 1989).

Our data indicate that such a belief is important for the bodybuilders: 19 among 30 people interviewed that explain they have chosen to commit in this sport because of an initial weakness. For example, Gaétan (25 years old, the 3rd in bodybuilding) tells us that:

I'm telling you, I had a physical complex, even as a child, I'm sure. And I was just thinking about it before coming, well, I think that most of the people who practice bodybuilding really in depth have some kind of complex deep inside, that's what I think. (personal communication, January 16, 2010)

It is the same for Kaïss (31 years old, has been committed in this sport for eight years):

Well, I felt I was skinny. I didn't go into bodybuilding to have a nice body for going to the beach, as they say. For me, it was more a question of putting on weight. It's true, I was full of complexes about that, cause I wanted to be sturdy, and get into competition with other guys. What I'm looking for is male comparison rather than female seduction. (personal communication, April 20, 2010)

Kaïss is certain that he is now more self-confident, thanks to the transformation of his body. In other words, bodybuilding has clearly filled a need for him: "I must admit I went into bodybuiding for that reason. In the end, I did not only aim at becoming sturdily built, I wanted to win, and unconsciously, I wanted to develop my 
self-confidence” (personal communication, April 20, 2010).

If we go back to Gaétan, there is a "before" and an "after" too:

That's exactly what I was about to tell you (affirmative tone). I'm not the same person, so to say, I mean, I feel better with myself ... even if, as I was telling you, I don't like to be stared at when I go to the beach, but still, I feel better, much better. And what's more, as I'm doing it mainly for myself, I feel even better, you know. (personal communication, January 16, 2010)

From this perspective, body investment in the practice of bodybuilding plays the role of liberation. That is what some women who do bodybuilding put into light. Such a sport gives strong and visible means "to be someone" in our societies and to produce "gender trouble" in particular (Butler, 1999): thanks to bodybuilding, you can break the rules in a male domination world (Hargreaves, 1994; Moore, 1996; Chapman \& Vertinsky, 2011; Felkar, 2012). Indeed, even if this sport field used to be only in the hands of men for several years and although male domination is still present nowadays, women have achieved to officially enter and this in a visible way, since the 1970s. More precisely, Bev Francis’ physical symbolizes that: when she exhibited her body at Ms Olympia in 1983, for the first time in the history of bodybuilding, not only did a woman show a muscular body, but a hypertrophied one, extremely streaked and "dry". That questioned what and where the borders between what gender categorizes as male and female are, as well as beauty and aesthetics norms of our societies (Johnson, 1996; Griffet \& Roussel, 2004).

To sum up, bodybuilding seems to have many advantages for the person who wants to be involved in it: thanks to the perpetual growth of the muscular mass, it would give access to wisdom that is a hobby for oneself leading to intimacy. But such a feeling would improve self-confidence too, which would be very useful in the interaction. As one among many other objects of our consumption societies, the body, in bodybuilding, would be a source of liberation. Nevertheless, such feelings are not always stabilized, because the body is a very labile capital, and because as another object of our consumption societies again, it does not satisfy its owner.

In bodybuilding, like in Sisyphus' myth, the end has no end: when you reach a level, you do not have to stop, because you tend to think that you can always do better and because you fear to lose your results. Even if the motivations and the degree of involvement of bodybuilders are plural (Monaghan, 2001), one can observe that the obsession of the body is common for more than $75 \%$ of our population, whatever the level of the bodybuilder. In other words, such observations are not isolated cases, numerous bodybuilders are actually body-minded. This reveals that in bodybuilding, there is an alienation dimension with body consumption, meaning that the body can be beyond control for the bodybuilder.

The obsessive side of bodybuilding can first entail risky behaviors. Among them, there is the question of doping. If it can be difficult to define clearly what is doping or not, we refer on this point to the regular consumption of forbidden products by the International Olympic Committee: steroids, growth hormone, insulin and diuretics especially. Four bodybuilders interviewed who consume such products, even if they do not compete, show by their testimonies that taking these drugs is rational for them to go further in their involvement. Bruno (42 years old, the 6th year of bodybuilding) use them both to gain mass and lose fat: "(As far as I'm concerned, I always want both... I want to try to gain mass, but without taking rubbish)": "Yes, exactly. Always going further. You'll never exceed your natural limits... once they're at their highest, then that's it. But, if you can take products to go even beyond that limit, well, just do it” (personal communication, January 8, 2010). He is conscious of the 
risks, but he seems to have evaluated them in comparison to the advantages such products can offer:

So, well, just go and have a look on the internet, just look for guys who have already taken some and who get a good grade, physically speaking. I wouldn't ask a bloke who weighs $50 \mathrm{kgs}$ to do that, you see. You need to be square and forthright, you know. And you must take stuff to protect your liver and your kidneys, that's of paramount importance. Many guys don't pay attention to that, you see, and then, they end up having their testicles all dried up, as well as everything else, and your kidneys too. Okay, you can take some, but be careful not to fall into this ..., try it first, yes, do. Just do one, or even two course treatments, no more, this will help you to develop, and after that, it's up to you to keep this balance, thanks to healthy food and efficient training. You'll also need rest. And don't say to yourself: "I'm gonna give myself a shot in the ass during summer, only to realize in winter that it makes no difference". (personal communication, January 8, 2010)

Mohamed cited above confirms: "I’ve gained mass, sure I have. It gives you so much, everything in fact: performance, stamina, almost everything. So many positive sides to it, you know. And negative sides too, but that's another story” (personal communication, March 4, 2010). Frédéric (38 years old, who has been doing bodybuilding for 20 years) is in the same case too:

Of course, you'll want to try, like everyone else, that's what you do in fact ... and either you realize that you're actually making progress, but then, it's getting quite expensive, and you think, well, if it costs you more than the result it brings you, well, if you have acne or such problems, then you stop. But everybody gives it a try, anyway. (personal communication, May 18, 2010)

The problem is that there are biological and social spillover effects with the consumption of such products: due to the positive neurological and social sensations they give, at least at the beginning, they create an incentive to always go further and overall, a strong dependence. Chris (32 years old, the 15th year in bodybuilding) knows it:

Such guys have no limits whatsoever, and then, about the anabolistic side of it, they cannot stop: first, they take one, two, then three doses. It's a sport about comparison: the bloke training next to you is better bodily-shaped than you, and so, you want to do like him. If he takes such or such product, then you'll do the same. It's always a question of over-doing it, all the time. But we're getting at the core of it ... this is the moment when it's beginning to get on you, you find yourself caught up in the system, just like a drug addict, it's exactly as if you were taking drugs, and you're saying to yourself: “I’ve got what I was looking for”, and now, in order to keep having what I want, I need to follow up taking that stuff. Well, okay, you take it as a course treatment, and you have the impression of being a drug addict ... but that's just because you've taken the stuff; that's what you're telling yourself”. (personal communication, June 3, 2010)

Secondly, besides doping, there are phenomena of overconsumption of the body that is a will to always train harder and harder. The fear and the deception of losing the results explain this, as Regis (39 years old, 22 years in bodybuilding) argues:

Yes, absolutely. I mean, there are times when I really don't want to go to the gym, but if I don't go, I will lose the benefits of all the training I've done, so sometimes, I feel I'm forced to do it. For instance, if I go on holiday somewhere and I can't train there, it's not that I feel ashamed when I come back, but the thing is, I don't feel well. Because it's not a question of fear, it's a feeling of disappointment, the fact that you've worked hard during a year or so, and you get good results, but then, as I was just telling you, after a holiday break or just a break like the one I had this year because of the flu, when you come back, it's as if you were going back to square one. And it's a known fact, in the eyes of other people. Often, you hear them say: "You've lost weight" or "What happened to you, have you got cancer?". (personal communication, April 2, 2010)

Frederic cited above sustains efforts in that direction, assimilating the practice to slavery: 
I can tell you, it turns out to be slavery, because you can't do without, really you can't. For you, it's real disaster, it is. If you go on a fortnight's holiday, you have to have a gym where you can train, it's a must. And this is not a good thing”. He admits he fears losing all he has gained: “That's the thing, you see. Once you've stopped for a week, you need two to make up for the lost time; and if you stop for two months, then you need three, it's horrible, you don't want to lose all you had gained. (personal communication, May 18, 2010)

That is why such a "too much" body also copes with all the psychosociological aspects of a bodybuilder's life: when he only defines himself by his body, he feels insecure. Such insecurity is not the same than the one which took place at the beginning of the involvement. It is now more about the fear of a lack of something, the sensation to be "less" than somebody else and to have not enough body. Then he is likely to develop pathologies like bigorexia or dysmorphophobia (Vallet, 2008). Kaïss cited above admits it:

Yes, that's true ... I often look at myself in the mirror, I do. You can actually see the progress you've made, you can see your nerves prominent, and so you can see the difference. But I must admit that, looking at myself in the mirror every day, I’m telling myself psychologically that I'm not big enough. (personal communication, April 20, 2010)

Mike (29 years old, 12 years in bodybuilding) thinks that his vision and his involvement in bodybuilding have a pathological side:

Oh, but it’s obsessional, I tell you it is. It’s obsessional, because honestly, whenever I see a mirror, I look at myself, I do. Believe me, it's compulsive. When I see a mirror, I can't help looking at myself; when I eat, I can't help touching my stomach, just to make sure I have not put on fat. It is obsessional, because before, when I saw a hefty man, it was a real problem for me, but now that I'm a teacher, it's gone, don't ask me why, something must have changed in my mind; I mean, when I used to see a really well-built man in the same room as me, I would suddenly feel very bad, and I would leave the place. I felt completely drained. Let me tell you, I don't feel the same with a bodybuilder, because in that case, I'm impressed. But to see a guy the same age as me, heftier than me, and I would be in a terrible state, and leave the room because I was sick at heart. (personal communication, March 6, 2010)

Antoine always thinks about his body too:

You always think about it, really, once you're in it, after that, well, it's like a man running the marathon or the guys who go hiking, you don't train for a week, and then you feel heavier, your body craving for physical effort, but sure, you also have the "yes, I 'Il become less well-shaped, I have to go back" side, and this is not inconsiderable, in some way .... (personal communication, May 2, 2010)

It is likewise for Stéphane (33 years old, who has been doing bodybuilding for eight years):

To me, it's something that makes you fall, in a way ... well, as far as I'm concerned, it's sheer obsession, I'm positive about it. Because if I skip training, even for a day at least, I don't feel well ... I know I'm going to rest, and that's what I'm telling myself-_I'm having a good rest” or "I need to rest”- but if I had any sense, I would go to the gym. So, you see, it's sheer madness, that's what it is really, but then, you know, I force myself to rest, I take one or two days off each week. I think that what I end up telling myself is "if I went training, more and more, I would be able to make more progress”, and that's where you're very much mistaken, and that's when you have to know how to rest, in fact. You quickly fall into over-training, and that's a mistake. It’s catabolistic”. (personal communication, April 16, 2010)

In sum, such testimonies indicate that the production and the consumption of the body in bodybuilding only secures at best the "form" but the "core" of someone’s identity (Klein, 1993). This could then be a source of relative frustration and even alienation. 


\section{Conclusions}

Bodybuilding perfectly fits the main principles of our consumption societies. It both embodies and spreads values as hedonism, wealth, and individualism which are characteristic of them. Hence, through the investment of his body, someone could concretize such ideals as he decided, leading to a higher state of self-consciousness and wisdom. Symmetrically, bodybuilding is based on the application of economic principles that allow consumption: before being visible, the body has to be produced like any other good. That is why such a body has to be built thanks to rationalization, planning and calculation. Not only does the socioeconomic system of bodybuilding include training but also one's whole life too, due to the fact that the way to succeed in bodybuilding implies a "work for" some things and a "work against" other things that limit commitment (Darmon, 2008). This sense of life through body production and consumption could hence represent liberation for some people who find in bodybuilding a way to change themselves, that is to feel better and to gain value into social interactions.

Nevertheless, such behaviors could become obsessive. When you define all your life through what your body is and what it has to become, it could be risky, even dangerous. Indeed, in relation to other consumption societies' principles too, the body could be assimilated to an object that never satisfies its owner, implying that it finally is behind one's control. Clearly, such process is alienation. This example is "ironic" because it shows, although such sport was born with modernity that it takes some of its roots in Antiquity. Ancient norms of aesthetic, body concern, performance belong to current bodybuilding's principles as well as the fact that bodybuilding has unfortunately to do with Antic myths: it could help you to know yourself like Prometheus, but it could also pull you on a Sisyphus' path... where you lose yourself.

\section{References}

Amadieu, J. F. (2005). Le poids des apparences (The weight of appearances). Paris, Odile Jacob.

Baudrillard, J. (1998). The consumer society: Myths and structures (First Published in 1970). London: Sage Publications.

Baudry, P. (1991). Le corps extrême (The extreme body). Paris, L’Harmattan.

Bauman, Z. (2000). Liquid modernity. Cambridge: Polity Press.

Beck, U. (1992). Risk society: Toward a new modernity. London: Sage Publications.

Becker, H. S. (1963). Outsiders: Studies in the sociology of deviance. Chicago: Chicago University Press.

Berry, B. (2010). Making it big. Visible symbols of success, physical appearance, and sport figures. In E. Smith (Ed.), Sociology of sport and social theory (pp. 187-200). Champaign: Human Kinetics.

Berthelot, J. M. (1983). Corps et société. Problèmes méthodologiques posés par une approche sociologique du corps (Body and society. Methodological issues raised by a sociology of the body). Cahiers internationaux de sociologie (International Papers of Sociology), LXXIV, 119-131.

Blake, A. (1996). The body language: The meaning of modern sport. London: Lawrence \& Wishart.

Bonetti, M., De Gaulejac, V., Descendre, D. \& Pagès, M. (1998). L'Emprise de l'organisation (The influence of the organization) (First Published in 1979). Paris: Desclée de Brouwer.

Butler, J. (1999). Gender trouble. New York and London: Routledge.

Chapman, D. L., \& Vertinsky, P. (2011). Venus with biceps: A pictorial history of muscular women. Vancouver: Arsenal Pulp Press.

Chartier, R., \& Vigarello, G. (1982). Les trajectoires du sport. Pratiques et spectacles (The trajectories of the body. Practises and shows). Le débat (The Debate), 19, 34-58.

Darmon, M. (2008). Devenir anorexique. Une approche sociologique (To become anorectic. A sociological approach). Paris: La découverte.

Defrance, J. (2003). Sociologie du sport (Sociology of sport). Paris: Repères, Editions La Découverte. 
Denham, B.E. (2010). Masculinities and the sociology of sport: Issues and ironies in the 21st century. In E. Smith (Ed.), Sociology of sport and social theory (pp. 143-152). Champaign: Human Kinetics.

Duret, P., Griffet, J., \& Roussel, P. (2003). The Decline of Female Bodybuilding in France. Sociology of Sport Journal, 20 , 40-59.

Felkar, V. (2012). Marginalized muscle: Transgression and the female bodybuilder. Ignite, 4(1), 40-49.

Giddens, A. (1991). Modernity and self-identity: Self and society in the late modern age. Cambridge: Polity Press.

Goffman, E. (1963). Stigma: Notes on the management of spoiled identity. New York: Touchstone.

Griffet, J., \& Roussel, P. (2004). Le muscle au service de la beauté : la métamorphose des femmes culturistes (The muscles to serve the beauty: The metamophosis of female bodybuilders). Recherches féministes (Feminist Researches), 17(1), 143-172.

Hargreaves, J. (1994). Sporting females: Critical issues in the history and sociology of women's sports. New York: Routledge.

Johnson, L. (1996). Flexing femininity: Female body-builders refiguring "the Body”. Gender, Place \& Culture: A Journal of Feminist Geography, 3(3), 327-340.

Klein, A. M. (1993). Little big men: Bodybuilding subculture and gender construction. Albany: State University of New York Press.

Lasch, C. (1991). The culture of narcissism. London: W.W. Norton \& Company.

Luciano, L. (2001). Looking good. Male body image in the modern America. New York: Hill and Wang Editors.

Maisonneuve, J. (1976). Le corps et le corporéisme aujourd'hui (Body and bodily display nowadays). Revue française de sociologie (French Review of Sociology), XVII, 551-571.

Monaghan, L. F. (2001). Bodybuilding, drugs and risk. London: Routledge.

Moore, S. D. (1996). God's gym. New York and London: Routledge.

Perine, S. (2010). Controverse. Flex, 100, 74-80.

Prost, F. (2006). Corps primitif, corps archaïque. Anthropologie et archéologie de la représentation corporelle en Grèce ancienne (Primeval body, archaic body. Anthropology and archeology of the representation of the body in the ancient Greece). In F. Prost, \& J. Wilgaux (Eds.), Penser et représenter le corps dans l'Antiquité (How to think and to represent the body in the ancient world) (pp. 31-40). Rennes: Presses Universitaires de Rennes.

Queval, I. (2008). Le corps aujourd'hui (The body today). Paris: Gallimard.

Reynolds, B., \& Weider, J. (1989). Joe Weider's ultimate bodybuilding: The master blaster's principles of training and nutrition. Chicago: Contemporary Books Inc.

Rostow, W. (1991). The stages of economic growth: A non-communist manifesto. Cambridge: Cambrdige University Press.

Schwarzenegger, A. (1998). The new encyclopedia of modern bodybuilding. New York: Simon \& Schuster Paperbacks.

Schwarzenegger, A. (2013). Total recall. Paris: Pocket.

Shilling, C. (2012). The body and social theory. New York: Sage Publications.

Simmel, G. (2011). The philosophy of money. London: Routledge Classics.

Taranto, P. (2008). Le corps sportif: un corps imaginaire (The sporty body: An imaginary body). In D. Moreau, \& P. Taranto (Eds.), Activité physique et exercices spirituels. Essais de philosophie du sport (Physical activities and spiritual exercices. Essays on the philosophy of sport) (pp. 71-98). Paris: Librairie Philosophique Vrin.

Tocqueville, A. (2004). Democracy in America. New York: Library of America.

Turner, B. (2008). The body and society. London: Sage Publications.

Vallet, G. (2008). Corps performant bodybuildé et identité sexuée masculine: une congruence? (The powerful body in bodybuilding and the male identity: Do they go along with each other?). Revue Interrogations, 7, 148-167.

Vallet, G. (2013). Devenir bodybuilder. In P. Maréchaux (Ed.), Hercules de toujours (pp. 37-63). Paris: Editions Cécile Defaut.

Weber, M. (2012). The protestant ethic and the spirit of capitalism. New York: Routledge.

Young, D. C. (1984). The Olympic myth of Greek amateur athletics. Chicago: Ares Publishers. 